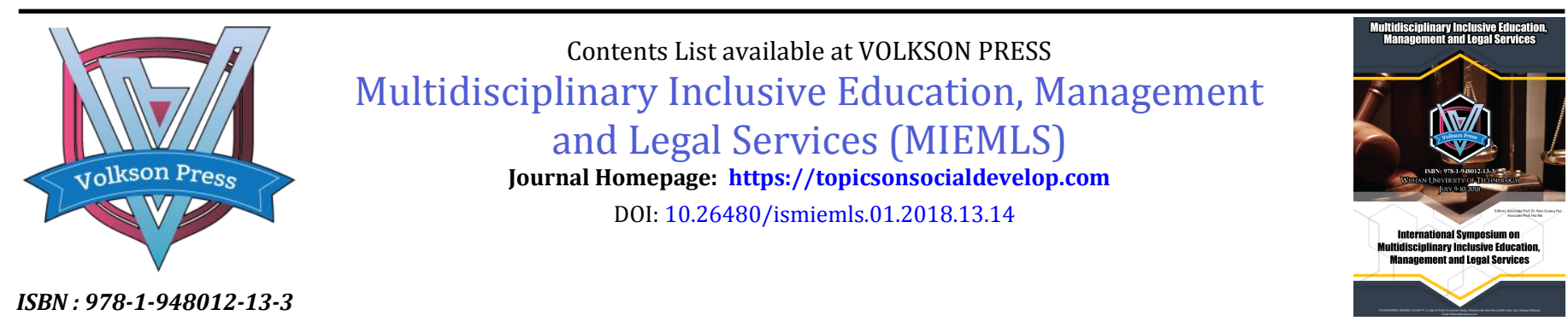

\title{
THE EFFECT OF TEST DATABASE ESTABLISHMENT ON MOLECULAR CELL BIOLOGY TEACHING
}

\author{
Ying Song*, Yun Bei, Ning Xu, Ben-fang Ruan, Le Li \\ College of Pharmaceutical Sciences, Zhejiang University of Technology, 18 Chaowang Rd., Hangzhou, 310014, PR. China. \\ *Corresponding author email: songying@zjut.edu.cn
}

This is an open access article distributed under the Creative Commons Attribution License, which permits unrestricted use, distribution, and reproduction in any medium, provided the original work is properly cited.

\section{ARTICLE DETAILS}

\section{Article History:}

Received 26 June 2018 Accepted 2 July 2018

Available online 1 August 2018

\section{ABSTRACT}

Molecular Cell Biology is a compulsory discipline for medical and pharmaceutical majors in colleges. It provides a decisive basis for further study on the physiological and pathological mechanism at the cellular or molecular level. Relevant colleges should be strict to check the completion test of this course and focus on improving the quality of education. Therefore, the establishment of test database and separation of teaching and testing have become a tendency in colleges these years. This review will analyze the influence of establishing the test database from variety of aspects.

\section{KEYWORDS}

Cell Molecular Biology, Test database, Quality of education.

\section{INTRODUCTION}

Cell Molecular Biology is a discipline which integrates innovative and frontier content. Since the discovery of DNA helical structures in the 1950s, and the subsequent invention of DNA recombination techniques, numerous biotechnology has sprung up such as genetic engineering, gene knockout, RNA interference and gene high-throughput sequencing techniques, until recently invented the efficient CRISPR/Cas9 (Clustered regularly interspaced short palindromic Repeats/Cas9) gene targeted knockout techniques [1]. These technologies have greatly facilitated the study of life science from microscopic, ultramicroscopic to molecular levels. Thanks to these new biotechnologies, we can explain many complex life processes at the molecular level. In recent years, a large part of the Nobel Prize for Physiology and Medicine were awarded for the prizewinner to commend their research results in micro-cell molecular level. Hence, it is a wise method for colleges to expand their undergraduate course of such discipline at present. From the curriculum design in many universities, Cell Molecular Biology is a compulsory course which initiated at sophomore for undergraduate students and the teaching achievements were assessed by the exam and evaluate system. This review will explain the necessity of establishing the test database of this subject and its effect on teaching quality from the following aspects.

\section{THE NECESSITY OF ESTABLISHING TEST DATABASE}

The disadvantages of the traditional teaching model of the integration education with examination were mainly found in the following two aspects: teachers will teach selectively and pay more attention about the core knowledge according to the examination, then will making the students learning segmentary. On the other hand, gradually narrow thinking in the class will increasingly become the drawbacks of lecturing for exams. Teachers set questions in traditional way will lead students to studious review for the examination. When final exam week comes, most students will recite all night more struggling on what they have learned. Temporary forced memory is easy to be forgot, and it is not a desirable way to master medical knowledge. To improve the traditional teaching mode of the integration education with examination in colleges and universities at present, it is exceedingly meaningful for teachers and students to establish the online teaching platform of individual specialized courses and the intelligent learning platform which including the test database. And it is a general trend to establish a network platform which can complete the intelligent topic-setting work of cell molecular biology. In addition, based on the specificity of the course content which involves a large number of cutting-edge development, the difficulty of the teacher's preparation will be increased. Because of preparation of the test paper will cost teacher a lot of time and energy. Therefore, establishment of Cell Molecular Biology test database is a great choice. The quality of test database can also be used to discriminate the level of teaching research group teachers in universities, achieving the goal of the separation of teaching and examination, perfecting the construction of the style of studying, the style of teaching, and the school spirit, improving the standardization and scientization of educational administration.

\section{HOW TO BUILD A TEST DATABASE}

The development of question database involves many aspects, but it is mainly related to the quality of the test questions. The excellent question database should be covers the classic examples in syllabus, original questions, and the comprehensive test questions combined with frontier research results. The test database should have the following characteristics: 1 . Large number of questions. 2. Covered all knowledge points. 3. Have no repetition between questions. 4. Questions should be set intelligently. Before establish test database, the following preliminary preparations need to be mentioned.

\subsection{Grasp the scope of the syllabus}

At present, there are still some objection sound to the establishment of Test database system, the main reason is questions set from the traditional test database may above students' levels. Another reason is the that it is not easy to control the degree of difficulty. If the test paper is set at random, what can lead to the test time unmanageable. All these above will cause complain about examination from students. In response to these circumstances, the designer of the test database must define the syllabus of cell molecular biology and grip the knowledge points to set questions. 


\subsection{Screen original questions}

On the basis of renovating a large number of existing classical questions, the teacher should set the questions independent and combine the content of textbooks, grasp the accuracy and representativeness of the questions. With the development of cellular molecular biology, different research teams will publish the latest experimental results at each stage. For example, the latest report on the first birth of somatic cell cloned monkeys in China, it can be extended from the teaching materials in the relevant knowledge points to test [2]. So, the design of test database platform should take the convenience of entering the editing mode at any time into account. These cutting-edge theories of innovation are likely to improve or even overturn the understanding of the mechanisms of the microworld. Combining the characteristics of this subject, the angle of the questions should be more inclined to explain the molecular mechanism, besides, set questions according to the current research priority can grasp the pulse of development more accurately. leading undergraduate students to develop independent thinking habits.

\subsection{Classification of task types and calibration of difficulty}

General exam questions of the final examination papers have two major categories include objective questions and subjective questions. The objective questions related to the subject of cell molecular biology include filling out questions, selecting questions, judging questions, and the subjective question has the noun explanation, simple answer. The classification of the questions can greatly reduce the workload in the later period, and after each question should be labeled difficulty coefficient, in order that intelligent platform can get a qualified paper by arrange the combination of the different types of questions according to the difficulty of the test questions.

\section{THE INFLUENCE OF THE CONSTRUCTION OF TEST DATABASE NETWORK TEACHING PLATFORM ON TEACHING REFORM}

Cell molecular biology is a rapid development subject, a lot of knowledge are from the practice of scientific research, although theoretical knowledge seems like an armchair, when the two are combined will play a different effect, therefore, the examination method of the question database combined with the network teaching platform as the evaluation of the students' innovative ability in the second classroom will lead to the new trend of Internet teaching. The cell molecular biology is a discipline which pays attention to the picture, the dynamic teaching, how to realizes the static teaching material color illustration transforms to the dynamic process is the key point in future teaching. Humanized and flexible test questions database will give undergraduate teaching a huge auxiliary function.

\subsection{For teaching staffs}

The construction of the question bank of cell molecular biology needs all the teachers of the teaching and research group to work together to complete the project. In this process, it can also improve the teachers' professional foundation level and re-examine the course contents from the proposition angle, make the difficult knowledge easy to impart in class. However, considering that the knowledge of the syllabus is numerous and the time is limited, it may be a severe test to the teacher's teaching method if set the question at random from the question bank. To a certain extent, the establishment of the question bank can not only avoid the occurrence of leakage events of classroom teachers, but also urges the teachers of cell molecular biology to keep their lesson preparation content with the times, add the latest research progress at this stage on the basis of the original teaching materials, so as to guarantee the initiative of the students' examination.

\subsection{For students}

Essential subjects for medical science such as cell molecular biology, students need to understand it knowledge points at first if they want to remember it. And the correlation between the relevant knowledge points is also far greater than other categories of subjects. The establishment of test bank can effectively improve students' enthusiasm for learning and reduce the phenomenon of playing mobile phones in class. When the teachers started the first lecture, they would ring alarm bells for the students. Although this form will greatly reduce the pass rate, it will ensure that the students' achievement of the final grade will be fair and impartial. Separation of teaching and examination can realize the application of teaching as the goal, and the driving force of students learning is to explore the potential pathway more than to deal with the examination. The test question bank should be opened to students in the form of setting questions intelligently in each chapter. students can check the situation through on-line questions after completing a chapter study and teachers can also be able to understand the student's study progress in this backstage at any time. Both of them can also discuss the problem with each other to make teaching and learning effect more perfect.

\section{POST MAINTENANCE OF TEST DATABASE}

Once the library of cell molecular biology tests is completed, it does not mean that teachers can do it once and for all. In the process of use, the maintenance personnel of the platform should regularly check the correctness of the test questions in the test question bank, accept the students' feedback after doing the questions, eliminate the outdated theory, increase the timeliness issues in time, and gradually introduce new ones. The molecular biology of cells is a course that displays dynamic processes, so we can consider uploading animated videos of receptors, genes, proteins in the cytoplasm at the micro-molecular level on the network platform of test question banks. This will not only inspire students to the degree of love of the course can but also deepen the visual memory of a series of obscure knowledge.

\section{PROSPECT}

It is easily concerned that the Internet platform and contemporary media will drive the development of the life sciences [3] . It will combine the test bank of cell molecular biology with the influence of superstar teaching. Students will be able to use their spare time to study and consolidate their professional knowledge and learn how to grasp their mastery questions. The intelligent test question bank can make teachers spare no efforts to scientific research due to it save a lot of energy for the final roll. It can also motivate contemporary college students to study independently and understand professional knowledge in depth. Undergraduate teaching combined with students' multi-faceted learning situation to do the fullscale quality assessment method meets the assessment requirements of medical specialty certification, achieved goals that the assessment of academic performance must be aimed at educational; In order to and provide a strong basis for improving the concept of quality education in the new era, advocating the use of formative evaluation methods at ordinary times; advocating the use of interdisciplinary integration test items; emphasizing the use of modern technologies and methods is necessary [4].

\section{ACKNOWLEDGMENTS}

This work is supported by the Graduate teaching reform foundation of Zhejiang University of Technology (No. 2017112) and Advanced education class teaching reform project of Zhejiang province (No. kg20160066).

\section{REFERENCES}

[1] Liu, Z., Cai, Y., Wang, Y., Nie, Y., Zhang, C. 2018. Cloning of Macaque Monkeys by Somatic Cell Nuclear Transfer. Cell, 172, 881-887.

[2] Shorbagi, S., Ashok, A. 2016. Designing an Audiocast Assignment: A Primary-Literature-Based Approach that Promotes Student Learning of Cell and Molecular Biology through Conversations with Scientist Authors. J. Microbiol Biol Educ., 17, 472.

[3] Song, Y., Xiao, Y., Song, B., Feng, H. 2016. Using Contemporary Media as Supplementary Tool to Improve Pharmacology Education on College Synthetically.

[4] Thurtle-Schmidt, D.M., Lo, T.W. 2018. Molecular biology at the cutting edge: A review on CRISPR/CAS9 gene editing for undergraduates. Biochem Mol. Biol. Educ., 46, 195-205. 